This PDF is a selection from a published volume from the National Bureau of Economic Research

Volume Title: Financial Markets Volatility and Performance in Emerging Markets

Volume Author/Editor: Sebastian Edwards and Márcio G.

P. Garcia, editors

Volume Publisher: University of Chicago Press

Volume ISBN: 0-226-18495-1

Volume URL: http://www.nber.org/books/edwa05-1

Conference Date: December 1-3, 2005

Publication Date: March 2008

Title: Financial Openness, Currency Crises, and Output Losses Author: Sebastian Edwards

URL: http://www.nber.org/chapters/c4775 


\section{Financial Openness, Currency \\ Crises, and Output Losses}

Sebastian Edwards

\subsection{Introduction}

In early March, 2006, India's Prime Minister Manmohan Singh, announced that his country would take measures toward making the rupee a convertible currency. Capital controls would be dismantled, and freer international mobility of capital would be allowed. ${ }^{1}$ This step was unthinkable only a few years back; for decades analysts associated India with a strict policy of capital controls and restrictions. Indeed, in his criticism of the International Monetary Fund (IMF), Stiglitz (2002) argued that the fundamental reason why India and China had been spared from massive currency crises was that they did not allow free capital mobility. Stiglitz went even further and argued that the easing of controls on capital mobility was at the center of most (if not all) of currency crises in the emerging markets during the last decade-Mexico 1994, East Asia 1997, Russia 1998, Brazil 1999, Turkey 2001, and Argentina 2002.

Whether capital controls are beneficial for emerging countries continues to be a controversial issue among experts. Those authors that support capital controls have argued two important benefits: (a) capital controls reduce a country's vulnerability to external shocks and currency crises, and (b) they allow countries that have suffered a currency crisis implement progrowth policies and emerge out of the crisis sooner than what they would have done if otherwise. According to supporters of restricting the

Sebastian Edwards is the Henry Ford II Professor of International Business Economics at the Anderson Graduate School of Management at the University of California, Los Angeles, and a research associate of the National Bureau of Economic Research.

I thank Roberto Alvarez for his comments and excellent assistance. Discussions with Igal Magendzo have been very helpful.

1. See "India Plans to Remove Controls on the Rupee," Financial Times, March 20, 2006. 
capital account, controlling capital outflows would give crises countries additional time to restructure their financial sectors in an orderly fashion. ${ }^{2}$ The overall argument of controls supporters may be summarized as follows: "stricter controls on capital mobility reduce the costs of external crises in emerging countries."

Interestingly, most of the evidence in support of this claim has been country specific. There have been no attempts at analyzing large data sets that would include the experience in many countries. In part, this paucity of empirical analyses is the consequence of the difficulty in measuring the degree of capital mobility accurately (Eichengreen 2001). In this paper I use a broad multicountry data set to analyze the relationship between restrictions to capital mobility and currency crises. The analysis focuses on two definitions of currency crises: (a) a substantial change in an index of macroeconomic stability, calculated as a weighted average of nominal exchange rate changes and changes (declines) in the stock of international reserves $^{3}$ and (b), a significant change in the nominal exchange rate that is not accompanied by a (very) large change in international reserves. I am particularly interested in addressing the following two specific questions:

- What are the effects of these two different types of crises on real economic growth?

- Does this effect depend on the degree of capital mobility in the country in question?

Both of these questions are related to the "contractionary devaluation" issue, first addressed by Hirschmann (1949) and Diaz-Alejandro (1963, 1965 ) and recently discussed by a number of authors including Calvo (1999) and Cespedes, Chang, and Velasco (2004). In traditional open economy models in the Mundell-Fleming tradition, a currency depreciation is expansionary and results in an increase in aggregate demand. This is because the depreciation encourages net exports, without affecting other economic aggregates such as investment or consumption. ${ }^{4}$ However, as Hirschmann and Diaz-Alejandro point out, in more complete models there are a number of reasons why a depreciation may be contractionary, at least in the short run. This could be the case, for instance, if exports use imports as intermediate inputs, or if there are distortions in the credit market, or if the depreciation generates a substantial negative wealth effect that affects negatively consumption or investment (Edwards 1989). Recently, a number of

2. Most well-trained economists would agree that there are trade-offs associated with the imposition of capital controls. Whether the costs offset the benefits is a complex empirical question, whose answer will depend on the specificities of each particular country. Doing a full-blown cost-benefit analysis is well beyond the scope of this paper, however.

3. This is the traditional definition of "external crisis" proposed by Eichengreen, Rose, and Wyplosz (1996).

4. This assumes that the Marshall-Lerner condition holds. 
authors have revisited the question of whether currency depreciations are contractionary in the context of the "fear of floating" debate (Calvo and Reinhart 2002). These authors, among others, have argued that because in emerging countries many firms issue dollar-denominated debt, a large depreciation generates significant "balance sheet effects." These may be so large that they may more than offset the positive effects of a weaker currency on net exports. If this is indeed the case, an exchange rate depreciation will result in output contraction. From an empirical perspective, an important question refers to the magnitude of these effects and whether they are different for different types of currency crises. In addition, from a policy standpoint, it is important to investigate if these contractionary effects are different in countries with different degrees of capital mobility. I address these two questions in this paper.

The rest of the paper is organized as follows: In section 3.2 I discuss the evolution of capital account restrictions during the last thirty years. The section opens with an analysis on the evolution of capital account openness based on a new index, which I have constructed by combining three data sources: (a) the index developed by Quinn (2003); (b) the index by Mody and Murshid (2002); and (c) country-specific information obtained from various sources, including country-specific sources (see Edwards [2005] for further details). Section 3.3 deals with the anatomy of the two types of currency crises described in the preceding. This analysis is performed for three groups of countries classified according to the degree of capital mobility: "low capital mobility," "intermediate capital mobility," and "high capital mobility" countries. My main interest in this analysis is to compare the two extreme groups: low and high capital mobility. In section 3.4 I report new results on the costs of external crises. I am particularly interested in determining if the cost of these three types of crises-measured in terms of lower growth - is different for countries with different degrees of capital mobility. Finally, in section 3.5 I provide some concluding remarks. The paper also has a data appendix.

\subsection{Thirty Years of Capital Mobility in the World Economy}

In this section I discuss a new index on capital mobility, which was introduced in Edwards (2005). I then analyze the evolution of restrictions to capital mobility in the last three decades. The section ends with a brief analysis of recent (last decade) episodes of capital account liberalization.

During the decade and a half, there has been an increase in the degree of international capital mobility. There is not complete agreement, however, on the exact magnitude of this phenomenon. The reason for this is that it is very difficult to measure in a precise way a country's degree of capital mobility. Indeed, with the exception of the two extremes - absolute freedom or complete closeness of the capital account - it is not easy to provide 
effective measures that capture the extent of capital market integration. What has been particularly challenging has been constructing indexes that allow for useful comparisons across countries and across time. ${ }^{5}$

In order to analyze the evolution of capital account restrictions, I constructed a new index on capital mobility that combines information from Quinn (2003) and Mody and Murshid (2002), with information from country-specific sources. ${ }^{6}$ In creating this new index, a three-steps procedure was followed: first, the scales of the Quinn and Mody and Murshid indexes were made compatible (see Edwards [2005] for further details). The new index has a scale from 0 to 100, where higher numbers denote a higher degree of capital mobility; a score of 100 denotes absolutely free capital mobility. Second, I use STATA's "impute" procedure to deal with missing observations in the new index. In order to impute preliminary values to the missing observations, I use data on the two original indexes (Quinn and Mody and Murshid), their lagged values, openness as measured by import tariffs collections over imports, the extent of trade openness measured as imports plus exports over gross domestic product (GDP), a measure of openness obtained from the fitted values of a gravity model of trade and GDP per capita. ${ }^{7}$ In the third step, I use country-specific data to revise and refine the preliminary data created using the impute procedure discussed in the preceding. The new index covers the period 1970 to 2000 and has data for 163 countries (although not every country has data for every year). It is important to note that although this new index represents an improvement over alternative indexes, it still has some shortcomings, including the fact that it does not distinguish very sharply between restrictions on capital inflows and restrictions on capital outflows. ${ }^{8}$

Figure 3.1 depicts the evolution of the index for six groups of countries: (1) Industrial; (2) Latin America and the Caribbean; (3) Asia; (4) Africa; (5) Middle East and North Africa; and (6) Eastern Europe. This figure shows that the degree of capital mobility has increased in every one of these six regions during the last three decades. A comparison of the 1970 to 1989 and the 1990 to 2000 period suggests that, on average, the industrial countries made the most progress in moving toward greater capital mobility. The Middle East and North African (MENA) region, on the other hand, experienced only moderate capital account liberalization. Figure 3.1 also shows that this process of financial openness has followed different patterns in the

5. Some studies that have attempted to measure the degree of capital mobility include Edwards (1989), Klein and Olivei (1999), Leblang (1997), Razin and Rose (1994), Chinn and Ito (2002), Montiel and Reinhart (1999), Quinn (1997), Edison et al. (2004), Quinn and Toyoda (2003), Mody and Murshid (2002), Miniane (2004), and Quinn (2003).

6. For greater details, see Edwards (2005).

7. See Aizenman and Noy (2004) on the relationship between trade account openness and capital account openness.

8. See the discussion in the preceding section for an analysis of the shortcomings of different indexes. See also Eichengreen (2001) and Edwards (1999). 


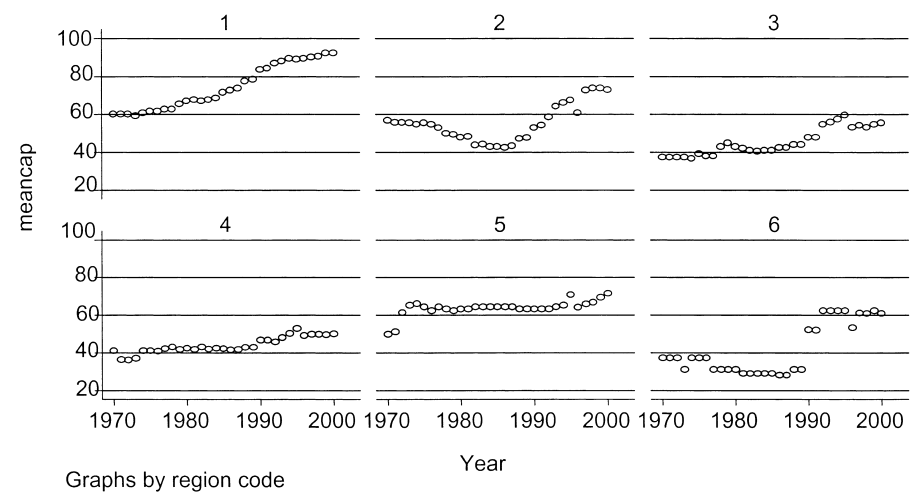

Fig. 3.1 Capital mobility index, 1970-2000

Notes: $1=$ Industrial countries, $2=$ Latin American and Caribbean, $3=$ Asia, $4=$ Africa, $5=$ Middle East, and $6=$ Eastern Europe.

different regions. For instance, in the industrial countries, it has been a relatively smooth process. In the Latin American countries, the story is quite different. As may be seen, the region had stricter capital account restrictions during the 1970s and 1980s; during the 1990s, on the other hand, the region experienced an increase in capital mobility. In Asia, there was an increase in capital mobility during the early 1990s, followed by a somewhat abrupt imposition of controls after the 1997 crises. Since then, capital mobility has increased somewhat. Eastern Europe is the region that has experienced the greatest discrete jump in the degree of capital mobility.

I divide the sample into three equal-size groups depending on the extent of mobility. These groups have been labeled High, Intermediate and Low mobility. ${ }^{9}$ This three-way division of the sample clearly captures the fact that the degree of capital mobility has increased significantly during the last thirty years. In 1970, 44 percent of the observations corresponded to Low mobility, 26 percent to Intermediate, and 30 percent to High mobility. In the year 2000 , in contrast, 24 percent of the observations corresponded to Low mobility, 25 percent to Intermediate, and 52 percent to High mobility. Table 3.1 contains summary data on the index of capital mobility for the Low and High mobility groups. ${ }^{10}$ As may be seen, the mean and median values of the index are very different across groups. Indeed a

9. Because the unit of analysis is a country/year observation and there has been a trend toward higher capital mobility (see figure 3.1), most observations in the High mobility group correspond to recent country/year observations. Likewise, by construction most (but by no means all) observations in the Low mobility group correspond to early (1970s and 1980s) country/year observations.

10. In much (but not all) of the analysis that follows I will deal only with the Low and High mobility groups. That is, in many of the results that follow the group of countries with Intermediate mobility has been dropped. 
Table 3.1

Capital mobility index by groups

\begin{tabular}{lccc}
\hline Group & Mean & Median & $\begin{array}{r}\text { Standard } \\
\text { deviation }\end{array}$ \\
\hline Low capital mobility & 30.0 & 37.5 & 9.9 \\
High capital mobility & 82.5 & 87.5 & 12.3 \\
\hline
\end{tabular}

test with the equality of means indicates that the null hypothesis is rejected at a high degree of confidence $(t$-statistic $=136.9)$.

In table 3.2, I present a list of nations with what I call "Very High" and "Very Low" capital mobility. These two groups focus on the "extremes" of the distributions and capture countries with an index value equal or higher than 87.5 (for Very High) and an index value lower or equal to 12.5 (Very Low). ${ }^{11}$ As may be seen, while the number of countries with Very High capital mobility increased from decade to decade, the number with Very Low mobility declined, until the 1990 to 2000 decade there were no nations with an index value below 12.5 .

\subsection{The Anatomy of Currency Crises: Is There a Difference between High and Low Capital Mobility Countries?}

\subsubsection{Currency Crises: Definition}

In this section, I investigate the nature of currency crises in the world economy during the last thirty years. I am particularly interested in finding out whether currency crises have had a higher incidence in countries with a high degree of capital mobility.

The first step in this analysis is the construction of two indexes of currency crises. The starting point is the definition of an index of "external pressures" along the lines suggested by Eichengreen et al. (1996):

$$
I_{t}=\frac{\Delta e}{e}-\left(\frac{\sigma_{e}}{\sigma_{i t}}\right) \cdot\left(\frac{\Delta R}{R}\right),
$$

where $(\Delta e / e)$ is the rate of change of the nominal exchange rate, and $(\Delta R /$ $R)$ is the rate of change of international reserves. A positive value of $(\Delta e / e)$ represents a depreciation. $\sigma_{e}$ is a standard deviation of changes in exchange rates, and $\sigma_{R}$ is the standard deviation of changes in international reserves. Traditional analyses define a crisis $\left(C_{t}\right)$ to have taken place when the index in equation (1) exceeds the mean of the index plus $k$ standard deviations.

11. These break-points were selected in an arbitrary fashion. 


\begin{tabular}{|c|c|c|c|c|c|}
\hline \multicolumn{6}{|c|}{ Very high capital mobility } \\
\hline \multicolumn{2}{|l|}{ 1970-1979 } & \multicolumn{2}{|l|}{ 1980-1989 } & \multicolumn{2}{|l|}{$1990-2000$} \\
\hline Bahrain & 87.5 & Antigua and Barbuda & 87.5 & Austria & 87.5 \\
\hline Gambia, The & 87.5 & Bahrain & 87.5 & Belgium & 96.6 \\
\hline Germany & 96.3 & Germany & 98.8 & Canada & 100.0 \\
\hline Hong Kong, China & 95.0 & Hong Kong, China & 100.0 & Denmark & 100.0 \\
\hline Lebanon & 87.5 & Kuwait & 87.5 & Estonia & 87.5 \\
\hline Panama & 100.0 & Lebanon & 87.5 & Finland & 95.4 \\
\hline Switzerland & 93.8 & Netherlands, The & 92.5 & France & 90.9 \\
\hline United Arab Emirates & 87.5 & Panama & 95.0 & Germany & 100.0 \\
\hline \multirow[t]{20}{*}{ United States } & 95.0 & Singapore & 100.0 & Guatemala & 100.0 \\
\hline & & Switzerland & 100.0 & Guatemala & 100.0 \\
\hline & & United Arab Emirates & 87.5 & Ireland & 93.1 \\
\hline & & United Kingdom & 100.0 & Italy & 96.6 \\
\hline & & United States & 100.0 & Kuwait & 87.5 \\
\hline & & Uruguay & 95.0 & Kyrgyz Republic & 87.5 \\
\hline & & Vanuatu & 87.5 & Latvia & 87.5 \\
\hline & & & & Lebanon & 87.5 \\
\hline & & & & Lithuania & 87.5 \\
\hline & & & & Netherlands, The & 100.0 \\
\hline & & & & New Zealand & 93.1 \\
\hline & & & & Norway & 100.0 \\
\hline & & & & Singapore & 97.7 \\
\hline & & & & Sweden & 87.5 \\
\hline & & & & Switzerland & 100.0 \\
\hline & & & & United Arab Emirates & 87.5 \\
\hline & & & & United Kingdom & 100.0 \\
\hline & & & & United States & 100.0 \\
\hline & & & & Uruguay & 93.1 \\
\hline & & & & Vanuatu & 87.5 \\
\hline \multicolumn{6}{|c|}{ Very low capital mobility } \\
\hline \multicolumn{2}{|l|}{ 1970-1979 } & \multicolumn{2}{|l|}{ 1980-1989 } & \multicolumn{2}{|l|}{$1990-2000$} \\
\hline China & 0.0 & Bangladesh & 12.5 & & \\
\hline Ethiopia & 12.5 & Iceland & 12.5 & & \\
\hline Iceland & 12.5 & Morocco & 10.0 & & \\
\hline Morocco & 3.8 & Sri Lanka & 12.5 & & \\
\hline South Africa & 7.3 & & & & \\
\hline Sri Lanka & 12.5 & & & & \\
\hline
\end{tabular}

Notes: Very high capital mobility countries are those with average mobility index higher or equal than 87.5. Very low capital mobility countries are those with average mobility index lower or equal than 12.5 . 
The crisis indicator $C_{t}$ takes a value of one (crisis) or zero (no crisis) according to the following rule: ${ }^{12}$

$$
C_{t}=\left\{\begin{array}{l}
1 \text { if } I_{t}>=\text { mean }\left(I_{t}\right)+\kappa \sigma_{I}, \\
0 \text { otherwise }
\end{array}\right.
$$

In this paper I use a value of $k=2$ to define the basic Crisis Index. An important characteristic of this index is that it is possible to have a crisis even if the exchange rate does not change in a significant way. That is, it is possible that the depletion in reserves is so significant, that on its own, it will move index $I$ by more than 2 standard deviations. In addition to the traditional index defined in equations (1) and (2), I construct an alternative crisis indicator that helps understand more fully the nature of the external crises. This indicator is exchange rate driven and detects crises where the currency depreciates very significantly, while international reserves do not decline in a substantial way. More specifically this alternative indicatorwhich I call "Exchange Rate Crisis" (Crisis_Er) — is defined as follows: The index takes a value of one if the change in the nominal exchange rate, by itself, triggers the $C_{t}$ crisis indicator in equation (2). Here the country lets the exchange rate depreciate significantly, before it has experienced a major loss in international reserves. That is, the country gives up defending the peg before international reserves suffer a major depletion.

\subsubsection{Currency Crises: Incidence}

Table 3.3 presents a summary of the occurrence of the two types of crises for the complete sample as well as for each one of the six groups of countries defined in figure 3.1. Table 3.3 also includes the Pearson tests for independence across groups. Three conclusions emerge from this table: (a) surprisingly perhaps, the more general type of crisis captured by the index Crisis Index has been a rather frequent event. ${ }^{13}$ For the sample as a whole, the incidence is 15.3 percent. The highest incidence is in Asia and the lowest in MENA; (b) the incidence of Crisis_Er is much lower than that of the combined crisis; 7.0 percent versus 15.3 percent (this is not surprising, given that the definition of Crisis_Er is stricter); and (c) the occurrence of Crisis_Er is statistically different across regions (see the chi-square statistic). ${ }^{14}$

12. The pioneer work here is Eichengreen, Rose, and Wyplosz (1996), who suggested that the index (2) also included changes in domestic interest rates. Most emerging and transition economies, however, don't have long time series on interest rates. For this reason, most empirical analyses are based on a restricted version of the index, such as 2 .

13. This is, in a way, by construction, since $k$ was chosen to be equal to 2 .

14. As it has been usually done in empirical work on crises, I also built alternative indicators that considered a three-year window after each crisis. The results, however, are very similar to those obtained when the basic definitions are used. For this reason, and due to space considerations, I don't report them in this paper. 
Table 3.3

Incidence of crises

\begin{tabular}{lcc}
\hline Region & Crisis index & Exchange rate crisis \\
\hline Industrial countries & 12.5 & 4.5 \\
Latin American and Caribbean & 14.1 & 6.8 \\
Asia & 17.5 & 6.4 \\
Africa & 15.5 & 8.3 \\
Middle East & 12.0 & 4.3 \\
Eastern Europe & 31.3 & 17.2 \\
Total & 15.3 & 7.0 \\
No. of observations & 3,710 & 3,695 \\
Pearson & & 34.1 \\
$\quad$ Uncorrected $\chi^{2}(5)$ & 33.0 & 6.8 \\
$\quad$ Design-based $\mathrm{F}(5,14710)$ & 6.6 & 0.00 \\
$P$-value & 0.00 & \\
\hline
\end{tabular}

\subsubsection{External Crises and Capital Mobility}

The analysis presented in the preceding, on two different types of crises (table 3.3), did not group countries according to their degree of capital mobility. In tables 3.4 and 3.5, I report their incidence for the two categories of capital mobility defined in the preceding: High, Intermediate, and Low capital mobility. The tables also present the $p$-values for Pearson tests on the equality of incidence under High mobility and Low mobility on the one hand, and equality of incidence under High mobility and Intermediate mobility, on the other hand (these tests are presented both at the countrygroup as well as aggregate levels). The results obtained may be summarized as follows:

- As may be seen from table 3.4, for the complete sample, the incidence of the broad definition of crisis (Crisis Index) is lowest in the high capital mobility countries. This is the case in every subgroup, with the exception of the Eastern European countries.

- Table 3.5 shows that for the Crisis_Er definition of crisis there is no significant diVerence in incidence across capital mobility categories, when the complete sample is analyzed. In three of the subgroups, however, the incidence of crisis is lowest in the High capital mobility countries: Industrial, Latin America, and Middle East.

The results presented in tables 3.4 and 3.5 were obtained when the contemporaneous value of the index was used to classify countries as having High, Intermediate, or Low degree of capital mobility. It is possible to argue, however, that what matters is not the degree of capital mobility in a particular year, but the policy stance on capital mobility in the medium term. In order to investigate whether an alternative classification makes a difference, I reclassified countries as High, Intermediate, and Low capital 
Table 3.4

Incidence of crisis index by categories of capital mobility

\begin{tabular}{lccccc}
\hline & & & & & \multicolumn{2}{c}{$t$-test } \\
\cline { 5 - 7 } Region & High & Intermediate & Low & $\mathrm{H}=\mathrm{I}$ & $\mathrm{H}=\mathrm{L}$ \\
\hline Industrial & 11.2 & 14.1 & 31.2 & 0.87 & $4.39^{* *}$ \\
Latin America and Caribbean & 10.9 & 13.6 & 17.4 & 0.97 & $2.40^{* *}$ \\
Asia & 13.9 & 23.5 & 17.5 & 1.88 & 0.97 \\
Africa & 17.7 & 15.6 & 15.0 & 0.61 & 0.80 \\
Middle East & 10.1 & 14.8 & 13.6 & 0.93 & 0.83 \\
Eastern Europe & 43.8 & 29.7 & 25.8 & 1.20 & 1.78 \\
Total & 12.8 & 16.2 & 17.0 & & \\
$P$-value & 0.00 & 0.07 & 0.01 & 0.02 & 0.00 \\
\hline
\end{tabular}

Note: $t$-test is in absolute values.

**Significant at the 5 percent level.

Table 3.5 Incidence of exchange rate crisis by categories of capital mobility

\begin{tabular}{lcccccc}
\hline & & & & & \multicolumn{2}{c}{$t$-test } \\
\cline { 5 - 7 } Region & High & Intermediate & Low & $\mathrm{H}=\mathrm{I}$ & $\mathrm{H}=\mathrm{L}$ \\
\hline Industrial & 3.3 & 6.6 & 9.8 & 1.65 & $2.44^{* *}$ \\
Latin America and Caribbean & 4.9 & 6.3 & 8.8 & 0.71 & 1.94 \\
Asia & 7.9 & 11.8 & 3.7 & 0.96 & 1.86 \\
Africa & 10.6 & 7.0 & 8.7 & 1.40 & 0.71 \\
Middle East & 1.9 & 9.3 & 5.7 & $2.47^{* *}$ & 1.61 \\
Eastern Europe & 25.0 & 20.0 & 11.5 & 0.48 & 1.69 \\
Total & 5.4 & 7.8 & 7.8 & & \\
$P$-value & 0.00 & 0.06 & 0.09 & 0.02 & 0.00 \\
\hline
\end{tabular}

Note: $t$-test in absolute values.

**Significant at the 5 percent level.

mobility using the average value in the index in the previous five years. The results obtained - not reported due to space considerations, but available on request - are very similar to those reported in tables 3.4 to 3.5.

\subsection{Capital Controls and the Costs of External Crises}

In this section, I investigate whether external crises - as defined by the two indicators proposed above - have historically had significant costs in terms of a lower GDP growth. More important, in terms of the current paper, I analyze whether the (potential) costs of external crises have been different in countries with different degrees of capital mobility. As pointed out earlier, this analysis deals with two important policy issues: the "contractionary devaluation" controversy and the discussion on the effective- 
ness of capital controls. The section is organized as follows: I first present a preliminary analysis, where I compare growth before and after the two types of crises, for countries with different degrees of capital mobility. I then present results obtained from an econometric analysis that uses random effect panel techniques to estimate the effects of external crises on deviation of growth from their long-run trend. As pointed out, the main interest in this analysis is to determine whether the extent of capital mobility plays a role in explaining the costs associated with crises.

\subsubsection{External Crises and Growth: A Preliminary Analysis}

In table 3.6, I present a before and after analysis on GDP per capita growth for the two definitions of crisis: Crisis Index and Crisis_Er. This analysis has been done for all countries, as well as for countries grouped according to their degree of capital mobility. The "before" data corresponds to average GDP per capita growth during the three years before the crisis. I have computed two "after" rates of growth: (a) the year of the crisis, and (b) the average during three years after the crisis. Panel A in table 3.6 contains the results for one year after the crisis; panel B contains results for three year after the crisis. The first four columns in both panels in table 3.6 contain the average difference in the rate of per capita growth for after and before the crisis (that is, it is defined as the rate of growth after the crisis, minus the rate of growth before the crisis). Column (1) is for all countries; columns (2) through (4) are for countries with High, Intermediate, and Low capital mobility. The numbers in parentheses are $t$-statistics for

Table 3.6

Before and after GDP per capita growth

\begin{tabular}{|c|c|c|c|c|c|c|}
\hline Event & $\begin{array}{l}\text { All } \\
\text { (A) }\end{array}$ & $\begin{array}{l}\text { High } \\
\text { (B) }\end{array}$ & $\begin{array}{c}\text { Intermediate } \\
\text { (C) }\end{array}$ & $\begin{array}{l}\text { Low } \\
\text { (D) }\end{array}$ & $\begin{array}{l}\text { High-Intermediate } \\
\text { (E) }\end{array}$ & $\begin{array}{l}\text { High-Low } \\
\text { (F) }\end{array}$ \\
\hline \multicolumn{7}{|c|}{ A. Year of crisis } \\
\hline Crisis_Index & $\begin{array}{l}-0.68 \\
(2.56)^{* *}\end{array}$ & $\begin{array}{l}-1.10 \\
(1.71)^{*}\end{array}$ & $\begin{array}{c}-0.29 \\
(0.69)\end{array}$ & $\begin{array}{l}-0.66 \\
(1.86)^{*}\end{array}$ & $\begin{array}{l}-0.81 \\
(1.06)\end{array}$ & $\begin{array}{c}-0.83 \\
(0.64)\end{array}$ \\
\hline Cri_Er & $\begin{array}{l}-0.75 \\
(1.80)^{*}\end{array}$ & $\begin{array}{l}-2.13 \\
(2.00)^{* *}\end{array}$ & $\begin{array}{c}-0.19 \\
(0.32)\end{array}$ & $\begin{array}{l}-0.33 \\
(0.56)\end{array}$ & $\begin{array}{l}-1.95 \\
(1.65)^{*}\end{array}$ & $\begin{array}{l}-1.81 \\
(1.63)\end{array}$ \\
\hline \multicolumn{7}{|c|}{ B. During three years after crisis } \\
\hline Crisis_Index & $\begin{array}{l}-0.12 \\
(0.65)\end{array}$ & $\begin{array}{l}-0.22 \\
(0.55)\end{array}$ & $\begin{array}{c}0.21 \\
(0.66)\end{array}$ & $\begin{array}{l}-0.27 \\
(1.04)\end{array}$ & $\begin{array}{l}-0.44 \\
(0.84)\end{array}$ & $\begin{array}{l}-0.25 \\
(0.11)\end{array}$ \\
\hline Cri_Er & $\begin{array}{c}0.00 \\
(0.02)\end{array}$ & $\begin{array}{l}-0.98 \\
(1.44)\end{array}$ & $\begin{array}{c}0.54 \\
(1.10)\end{array}$ & $\begin{array}{c}0.22 \\
(0.57)\end{array}$ & $\begin{array}{l}-1.53 \\
(1.84)^{*}\end{array}$ & $\begin{array}{l}-1.20 \\
(1.66)^{*}\end{array}$ \\
\hline
\end{tabular}

Notes: Crisis_Index is a broadly defined crisis; Cri_Er is exchange rate crisis. The "before" data corresponds to average GDP per capita growth during the three years before the crisis. In Panel A, "after" rates of growth is for year of the crisis. In Panel B, "after" is average growth rate during three years after the crisis. Absolute value of $t$-test in parentheses.

**Significant at the 5 percent level.

* Significant at the 10 percent level. 
the null hypothesis that the before and after rates of growth are equal. The final two columns are diffs-in-diffs columns, which report the difference in the before and after growth rates for High and Intermediate and High and Low capital mobility; that is the number in column (E) is equal to column (B) minus (C). The number in parentheses is for the null hypothesis that this diffs-in-diffs is equal to zero.

As may be seen from table 3.6, these (preliminary) results suggest that there are significant differences in the before and after rates of per capita growth when the shorter horizon is considered (panel A). These differences appear to be somewhat larger in the High capital mobility countries (column [2]). For the three-years horizon, the diffs-in-diffs result for Cri_Er in panel B suggest that there is a significant difference in the differences in per capita growth in countries with different degrees of capital mobility. Notice that only seven out of the twenty-four $t$-statistics in table 3.6 are significant at conventional levels. As emphasized in the preceding, however, these results are only preliminary as no attempt has been made to control for other factors or to incorporate the determinants of the probability of a crisis. ${ }^{15}$ In the subsection that follows I deal with these issues by using a random effect panel regression methodology.

\subsubsection{An Econometric Analysis}

In this subsection, I present results from an econometric analysis that deals with two questions: (a) do currency crises - as defined by the two indicators discussed in the preceding - have a negative effect on growth? and (b) does the degree of capital mobility affect the nature of this effect?

\section{Growth Effects of Currency Crises: Preliminary Econometric Results}

The point of departure of the empirical analysis is a two-equation empirical model for the dynamics of real GDP per capita growth of country $j$ in period $t$. Equation (3) is the long-run GDP growth equation, while equation (4) captures the growth dynamics process.

$$
\begin{gathered}
\tilde{g}_{j}=\alpha+\mathbf{x}_{\mathbf{j}} \beta+\mathbf{r}_{\mathbf{j}} \theta+\omega_{j} \\
\Delta g_{j t}=\lambda\left(\tilde{g}_{j}-g_{j t-1}\right)+\varphi v_{j t}+\gamma u_{j t}+\varepsilon_{j t}
\end{gathered}
$$

$\tilde{g_{j}}$ is the long-run rate of real per capita GDP growth in country $j ; \mathbf{x}_{\mathbf{j}}$ is a vector of structural, institutional and policy variables that determine longrun growth; $\mathbf{r}_{\mathbf{j}}$ is a vector of regional dummies; $\alpha, \beta$ and $\theta$ are parameters, and $\omega_{j}$ is an error term assumed to be heteroscedastic. In equation (4), $g_{j t}$ is the rate of growth of per capita GDP in country $j$ in period $t$. The terms $v_{j t}$ and $u_{j t}$ are shocks, assumed to have zero mean, finite variance, and to be uncorrelated among them. More specifically, $v_{j t}$ is assumed to be an exter-

15. Hong and Tornell (2005), however, have used a similar methodology and found that there are growth effects of crises. Their definition of crisis, however, is different from the two definitions I have used here. 
nal terms of trade shock, while $u_{j t}$ captures other shocks, including currency crises. $\varepsilon_{j t}$ is an error term, which is assumed to have a variance component form, and $\lambda, \varphi$, and $\gamma$ are parameters that determine the particular characteristics of the growth process. Equation (4) has the form of an equilibrium correction model and states that the actual rate of growth in period $t$ will deviate from the long-run rate of growth due to the existence of three types of shocks: $v_{j t}, u_{j t}$ and $\xi_{j t}$. Over time, however, the actual rate of growth will tend to converge toward its long-run value, with the rate of convergence given by $\lambda$. Parameter $\varphi$, in equation (4), is expected to be positive, indicating that an improvement in the terms of trade will result in a (temporary) acceleration in the rate of growth and that negative terms of trade shock are expected to have a negative effect on $g_{j t}{ }^{16}$

If, as posited by the contractionary devaluation hypothesis, large depreciations have a negative effect on growth, we would expect the coefficient $\gamma$ to be significantly negative. In the actual estimation of equation (4), I used dummy variables for the crisis indicators. An important question-and one that is addressed in detail in the subsection that follows - is whether the effects of different shocks on growth are different for countries with different degrees of capital mobility. I address this issue by adding to the estimation of equation (4) a term that interacts the crisis indicator with the index of capital mobility developed in the preceding.

Equations (3) to (4) were estimated using a two-step procedure. In the first step I estimate the long-run growth equation (3) using a cross-country data set. These data are averages for 1970 to 2001, and the estimation makes a correction for heteroscedasticity. These first stage estimates are then used to generate long-run predicted growth rates to replace $\tilde{g}_{j}$ in the equilibrium error correction model (4). In the second step, I estimated equation (4) using generalized least squares (GLS) for unbalanced panels; I used both random effects and fixed effects estimation procedures. ${ }^{17} \mathrm{I}$ calculate robust standard errors, clustered at the country level. The data set used covers 157 countries for the 1970 to 2001 period; not every country has data for every year, however. See the data appendix for exact data definition and data sources. In subsection 3.4.3, I present some extensions. The results from the first-step estimation of equation (3) are not reported due to space considerations. ${ }^{18}$

Table 3.7 presents the results from the second-step estimation of the

16. See Edwards and Yeyati (2005) for details.

17. Due to space considerations, only the random effect results are reported.

18. In estimating equation (1) for long-run per capita growth, I follow the by now standard literature on growth, as summarized by Barro and Sala-i-Martin (1995) and use average data for 1974 to 2000. In terms of the equation specification, I include the following covariates: the $\log$ of initial GDP per capita; the investment ratio; the coverage of secondary education; an index of the degree of openness of the economy; the ratio of government consumption relative to GDP; and regional dummies for Latin American, sub-Saharan African and Transition economies. The results are quite standard and support what by now has become the received wisdom on the empirical determinants of long-term growth. 
Table 3.7

Currency crises and growth (random effects GLS estimates)

\begin{tabular}{lcccc}
\hline & $(1)$ & $(2)$ & $(3)$ & $(4)$ \\
\hline Growth gap & 0.80 & 0.80 & 0.80 & 0.80 \\
& $(19.89)^{* * *}$ & $(19.68)^{* * *}$ & $(19.63)^{* * *}$ & $(19.53)^{* * *}$ \\
Change in terms of trade & 0.08 & 0.08 & 0.08 & 0.08 \\
& $(9.18)^{* * *}$ & $(9.21)^{* * *}$ & $(9.22)^{* * *}$ & $(9.25)^{* * *}$ \\
Crisis index & -0.91 & -0.82 & & \\
& $(3.72)^{* * *}$ & $(3.39)^{* * *}$ & & \\
Lagged crisis index & & -0.40 & & \\
& & $(1.56)$ & & -1.17 \\
Cri_Er & & & $(3.55)^{* * *}$ & $(3.36)^{* * *}$ \\
& & & -0.63 \\
Lagged Cri_Er & & & -0.31 & $(1.75)^{*}$ \\
& & -0.18 & -0.26 \\
Constant & $(2.02)^{* *}$ & $(1.51)$ & $(2.84)^{*}$ & $(2.41)^{* *}$ \\
& 1,971 & 1,971 & 1,971 & 1,971 \\
No. of observations & 91 & 91 & 91 & 91 \\
No. of countries & 0.52 & 0.53 & 0.53 & 0.53 \\
$R^{2}$ & & & & \\
\hline
\end{tabular}

Notes: Crisis index is a broadly defined crisis; Cri_Er is exchange rate crisis. Absolute value of $t$-statistics are reported in parentheses.

$* * *$ Significantly at the 1 percent level.

**Significant at the 5 percent level.

*Significant at the 10 percent level.

growth dynamics equation (3). The first two equations refer to the broad crisis indicator Crisis Index, while the next two equations focus on Crisis_Er. As may be seen, the results are quite interesting. The estimated coefficient of the growth gap is, as expected, positive, significant, and smaller than one. The point estimates are on the high side - in the neighborhood of 0.80 - suggesting that, on average, deviations between long-run and actual growth get eliminated rather quickly. Also, as expected, the estimated coefficients of the terms of trade shock are always positive and statistically significant, indicating that an improvement (deterioration) in the terms of trade results in an acceleration (deceleration) in the rate of growth of real per capita GDP relative to its long-term trend. As may be seen, the coefficients of both external crises indicators are significantly negative, providing support to the contractionary devaluation hypothesis. The point estimates for the Crisis_Er indicator is higher (in absolute values) than that for the broader index Crisis Index. This suggests that using international reserves to absorb part of the effects of a crisis helps reduce its impact on GDP growth. Finally, the results in table 3.7 indicate that lagged values of the crisis indicators are not significant at conventional levels and that the contractionary effect of an external crisis is concentrated on its first year. No- 
tice, however, that given the dynamics nature of equation (3), GDP growth remains below potential growth for quite some time.

\section{External Crises and Capital Mobility}

An important issue in policy debates is whether, as suggested by some authors such as Stiglitz (2002), countries that restrict capital mobility are able to reduce the costs of external crises. In order to investigate whether the degree of capital mobility affects the cost of an external crisis characterized by the two indicators defined in the preceding, in the estimation of the growth equation (4), I also included a variable that interacts each of the crisis indicators with the capital mobility index. The results obtained are reported in table 3.8. In the first two columns, I used the broader Crisis

Table 3.8 Currency crises, capital mobility, and growth (random effects GLS estimates)

\begin{tabular}{|c|c|c|c|c|}
\hline & (1) & (2) & (3) & (4) \\
\hline Growth gap & $\begin{array}{c}0.81 \\
(17.59)^{* * *}\end{array}$ & $\begin{array}{c}0.80 \\
(16.95)^{* * *}\end{array}$ & $\begin{array}{c}0.81 \\
(17.49)^{* * *}\end{array}$ & $\begin{array}{c}0.82 \\
(17.91)^{* * *}\end{array}$ \\
\hline Change in terms of trade & $\begin{array}{l}0.07 \\
(7.97)^{* * *}\end{array}$ & $\begin{array}{l}0.07 \\
(8.08)^{* * *}\end{array}$ & $\begin{array}{l}0.07 \\
(8.07)^{* * *}\end{array}$ & $\begin{array}{l}0.07 \\
(8.09)^{* * *}\end{array}$ \\
\hline Crisis index & $\begin{array}{l}-1.18 \\
(3.41)^{* *}\end{array}$ & $\begin{array}{l}-0.88 \\
(1.81)^{*}\end{array}$ & & \\
\hline Crisis index $\cdot$ Cap & $\begin{array}{c}0.005 \\
(0.65)\end{array}$ & $\begin{array}{c}0.001 \\
(0.15)\end{array}$ & & \\
\hline Lagged crisis index & & $\begin{array}{l}-1.00 \\
(1.91)^{* *}\end{array}$ & & \\
\hline Lagged crisis index $\cdot$ Cap & & $\begin{array}{c}0.011 \\
(1.31)\end{array}$ & & \\
\hline Cri_Er & & & $\begin{array}{c}-0.80 \\
(1.26)\end{array}$ & $\begin{array}{c}-0.55 \\
(0.89)\end{array}$ \\
\hline Cri_Er $\cdot$ Cap & & & $\begin{array}{l}-1.01 \\
(0.80)\end{array}$ & $\begin{array}{l}-0.01 \\
(1.32)\end{array}$ \\
\hline Lagged Cri_Er & & & & $\begin{array}{l}-1.32 \\
(1.84)\end{array}$ \\
\hline Lagged Cri_Er · Cap & & & & $\begin{array}{c}0.01 \\
(0.97)\end{array}$ \\
\hline Constant & $\begin{array}{c}-0.24 \\
(1.58)\end{array}$ & $\begin{array}{l}-0.18 \\
(1.51)\end{array}$ & $\begin{array}{l}-0.32 \\
(2.33)^{* *}\end{array}$ & $\begin{array}{l}-0.26 \\
(1.84)^{*}\end{array}$ \\
\hline No. of observations & 1,942 & 1,937 & 1,942 & 1,937 \\
\hline No. of countries & 90 & 90 & 90 & 90 \\
\hline$R^{2}$ & 0.52 & 0.53 & 0.52 & 0.53 \\
\hline
\end{tabular}

Notes: Crisis index is a broadly defined crisis; Cri_Er is exchange rate crisis; Cap is an index of capital mobility. Absolute value of $t$-statistics are reported in parentheses.

$* * *$ Significant at the 1 percent level.

**Significant at the 5 percent level.

*Significant at the 10 percent level. 
Index indicator of crisis; the two last columns are for the Crisis_Er indicator. As may be seen, the coefficient of the interacted variable is not significant in any of the regressions. In table 3.9, I investigate whether these results are affected by the sample used. In table 3.9, I present results obtained from emerging and transition countries only. The results, however, are very similar to those presented in the preceding: once again, the variable that interacts crisis and capital mobility is insignificant. This is the case in every regression.

The results reported here suggest that countries that restrict capital mobility have not expressed milder crisis than countries that allow for a freer mobility of capital. These results, then, are at variance with the position taken by a number of globalization critics that have argued that the presence of capital controls reduce the costs of crisis. These results, however, should be considered as preliminary. The issue deserves more attention, and additional research may result in different results. Three aspects of this analysis deserve particular attention. First, and as discussed in section 3.2 of this paper, measuring capital mobility is a difficult and challenging enterprise. Efforts should be made to improve the quality of these indexes. Second, alternative definitions of crises should be considered. It is possible that the degree of capital mobility has some effects on the way some types

Table 3.9

Currency crises, capital mobility, and growth (random effects IV estimates)

\begin{tabular}{lcc}
\hline & $(1)$ & $(2)$ \\
\hline Growth gap & 0.81 & 0.84 \\
& $(29.51)^{* * *}$ & $(23.78)^{* * *}$ \\
Change in terms of trade & 0.07 & 0.07 \\
& $(8.26)^{* * *}$ & $(7.94)^{* * *}$ \\
Crisis index & -5.11 & \\
& $(2.35)^{* *}$ & \\
Crisis index $\cdot$ Cap & 0.03 & \\
& $(0.68)$ & -8.93 \\
Cri_Er & & $(2.80)^{* * *}$ \\
Cri_Er $\cdot$ Cap & & 0.03 \\
Constant & & $0.53)$ \\
& 0.40 & 0.25 \\
No. of observations & $(1.47)$ & $(0.93)$ \\
No. of countries & 1,239 & 1,239 \\
$R^{2}$ & 66 & 66 \\
\end{tabular}

Note: See table 3.8 notes.

$* * *$ Significant at the 1 percent level.

** Significant at the 5 percent level. 
of crisis manifest themselves. Future research should concentrate on the consequences of sudden stops as well as on current account reversals. ${ }^{19}$ And third, there may be issues of endogeneity. It is possible - although in my opinion not very likely - that countries with decelerating growth are the ones that experience currency crises. In the subsection that follows, I address this specific issue, and I report results obtained when instrumental variables versions of equation (4) were estimated.

\subsubsection{Endogeneity and Robustness}

The results presented in tables 3.7 and 3.8 assume that both crisis and capital mobility are exogenous variables. However, as pointed out in the preceding, this needs not be the case. In this subsection I report the results obtained when equation (4) was estimated using an instrumental variables random effect procedure. I also discuss the results obtained when alternative time periods were used in the estimation and when different samples were considered. Finally, I investigate the role of (potential) outliers. As will be seen, the results are robust to these alternative estimation procedure and data sets and suggest that the effects of external crises on economic activity are not affected by the degree of capital mobility.

\section{Endogeneity}

As pointed out in the preceding, it is possible that capital controls are endogenous and that their level is affected - through political economy channels - by the level of economic activity. For instance, it is possible that the economic authorities restrict capital mobility when the economy enters into a slowdown and allow capital to move more freely when the economy is expanding. The external crises variables may also be endogenous and, thus, were also instrumented. The following instruments were used in the instrumental variables (IV) estimation of equation (4): a trade openness index computed by the fitted value of the imports plus exports to GDP ratio obtained from a gravity model of bilateral trade; ${ }^{20}$ a measure of unanticipated capital inflows; ${ }^{21}$ an index that measures the (lagged) incidence of sudden stops in the country's region; ${ }^{22}$ the lagged value of the current account balance; the lagged fiscal deficit to GDP ratio; lagged and current

19. In a recent paper on the growth consequences of current account reversals I found some weak and preliminary evidence suggesting that countries with a more open capital account experienced a higher growth reduction than countries with more restricted capital mobility.

20. Frankel and Cavallo (2004) have convincingly argued that this gravity-based index of openness is exogenous. Aizenman and Noy (2004) have shown that there is a close relationship between trade and capital account openness.

21. This was computed from the residuals of a random effect panel equation on capital flows to GDP for the countries in the sample.

22. I consider the same six regions as the ones used in the analysis reported in sections 3.2 and 3.3: Advanced countries, Latin America, Asia, Africa, Middle East and North Africa, and Eastern Europe. 
changes in the terms of trade; the log of per capita GDP in 1970; and regional dummies. The results obtained are reported in table 3.9. As may be seen, the estimated coefficients of the external crises indexes continue to be negative and statistically significant at conventional levels. The coefficients of the growth gap and of the terms of trade are significantly positive. Also, as in the results reported in table 3.8, the coefficient of the interactive variable is insignificant.

\section{Alternative Data Sets}

In order to investigate the robustness of the results I reestimated equation (4) for alternative time periods and samples. In particular, I considered data sets that covered the shorter 1982 to 2002 and 1987 to 2002 periods. I also reestimated equation (4) for emerging countries only. The results for these alternative data sets (not reported here due to space considerations, and available on request) confirmed the most important results from tables 3.7 and 3.8: (a) both types of external currency crises considered in this paper had negative effects on growth, and (b) there is no evidence indicating that these effects have been different in countries that restrict capital mobility than in countries with freer capital mobility.

\section{Outliers}

As a way to further investigate the robustness of the results I analyzed whether the estimates reported in the preceding had been influenced by outliers. I performed an influence analysis using Cook's distance estimators. The results indicate that the result obtained have not been affected by extreme or outlier observations.

\section{Concluding Remarks}

In this paper, I have used a broad multicountry data set to analyze the relationship between restrictions to capital mobility and external crises. The analysis focuses on two manifestations of external crises. The analysis has focused on the following important policy question: does the extent of capital mobility determine the depth of external crises - as measured by the decline in growth-once a crisis occurs? In analyzing these issues I relied on two complementary approaches: first, I used a methodology based on nonparametric tests. And second, I used a regression-based analysis that estimates the effects of external crises on the dynamics of economic growth. Overall, my results cast some doubts on the assertion that countries that restrict capital mobility fare better during a crisis than countries with freer mobility. These results cast doubts on the claims, made by a number of critics of globalization, that freer capital mobility amplifies external crises (Stiglitz 2002).

The issues discussed in this paper deserve more attention in the future. 
In particular, there are three aspects of this analysis that warrant additional research. First and foremost, measuring capital mobility is a difficult and challenging enterprise. Efforts should be made to improve the quality of these indexes. Although the measures of capital mobility used in this paper represent a clear improvement over previous indexes, they still classify countries in rather coarse groupings. Second, alternative definitions of crises should be considered. It is possible that the degree of capital mobility has some effects on the way some types of crisis manifest themselves. Future research should concentrate on the consequences of sudden stops as well as on current account reversals. And third, the analysis should be expanded to the determinants of the probability of countries experiencing a crisis. The question here is whether the extent of capital mobility affects the likelihood that a country will face a major external crisis.

\section{Appendix}

Table 3A.1

Description of the data

\begin{tabular}{|c|c|c|}
\hline Variable & Definition & Source \\
\hline $\begin{array}{l}\text { Index of capital } \\
\text { mobillity }\end{array}$ & $\begin{array}{l}\text { Index: (low mobility) to } 100 \text { (high } \\
\text { mobility) }\end{array}$ & $\begin{array}{l}\text { Author's elaboration based on } \\
\text { indexes of capital restrictions } \\
\text { computed by Quinn (2003), } \\
\text { Mody and Murshid (2002), } \\
\text { and on country-specific data. }\end{array}$ \\
\hline Growth gap & $\begin{array}{l}\text { Deviation from long-run economic } \\
\text { growth rate }\end{array}$ & Author's elaboration. See text. \\
\hline $\begin{array}{l}\text { Change terms } \\
\text { of trade }\end{array}$ & $\begin{array}{l}\text { Change in terms of trade-exports as } \\
\text { capacity to import (constant LCU) }\end{array}$ & World Development Indicators. \\
\hline Crisis Index & Dummy for broad definition of crisis & Author's elaboration. See text. \\
\hline Crisis Er & Dummy for exchange rate crisis & Author's elaboration. See text. \\
\hline
\end{tabular}

\section{References}

Aizenman, Joshua, and Ilan Noy. 2004. On the two way feedback between financial and trade openness. NBER Working Paper no. 10496. Cambridge, MA: National Bureau of Economic Research, May.

Barro, Robert J., and Xavier Sala-i-Martin. 1995. Economic growth. Cambridge, MA: MIT Press.

Calvo, Guillermo A. 1999. Fixed vs. flexible exchange rates: Preliminaries of a turnof-millennium rematch. University of Maryland. Mimeograph.

Calvo, Guillermo A., and Carmen M. Reinhart. 2002. Fear of floating. Quarterly Journal of Economics 117 (2): 379-408.

Cespedes, Luis F., Roberto Chang, and Andrés Velasco. 2004. Balance sheets and exchange rate policy. American Economic Review 94:1183-93. 
Chinn, Menzie, and Hiro Ito. 2002. Capital account liberalization, institutional and financial development. NBER Working Paper no. 8967. Cambridge, MA: National Bureau of Economic Research.

Díaz-Alejandro, Carlos F. 1963. A note on the impact of devaluation and the redistributive effect. Journal of Political Economy 71:577-80.

1965. Exchange rate devaluation in a semi-industrialized country: The experience of Argentina 1955-1961. Cambridge, MA: MIT Press.

Edison, Hali, Michael W. Klein, Luca Ricci, and Torsten Sloek. 2004. Capital account liberalization and economic performance: Survey and synthesis. IMF Staff Papers 52 (1): 220-56. Washington, DC: International Monetary Fund.

Edwards, Sebastian. 1989. Real exchange rates, devaluation and adjustment. Cambridge, MA: MIT Press.

. 1999. How effective are capital controls? Journal of Economic Perspectives 13 (4): 65-84.

-2005. Capital controls, sudden stops and current account reversals. NBER Working Paper no. 11170. Cambridge, MA: National Bureau of Economic Research, March.

Edwards, Sebastian, and Eduardo Levy Yeyati. 2005. Flexible exchange rates as shock absorbers. European Economic Review 49 (8): 2079-2105.

Eichengreen, Barry J. 2001. Capital account liberalization: What do cross-country studies tell us? The World Bank Economic Review 15:341-65.

Eichengreen, Barry J., Andrew K. Rose, and Charles Wyplosz. 1996. Contagious currency crises. NBER Working Paper no. 5681. Cambridge, MA: National Bureau of Economic Research, July.

Frankel, Jeffrey A., and Eduardo Cavallo. 2004. Does openness to trade make countries more vulnerable to sudden stops, or less? Using gravity to establish causality. NBER Working Paper no. 10957. Cambridge, MA: National Bureau of Economic Research, December.

Hirschmann, Albert. 1949. Devaluation and the trade balance: A note. Review of Economics and Statistics 31:50-53.

Hong, Kiseok, and Aaron Tornell. 2005. Recovery from a currency crisis: Some stylized facts. Journal of Development Economics 76 (1): 71-96.

Klein, Michael W., and Giovanni Olivei. 1999. Capital account liberalization, financial depth and economic growth. NBER Working Paper no. 7384. Cambridge, MA: National Bureau of Economic Research, October.

Leblang, David A. 1997. Domestic and systemic determinants of capital controls in the developed and developing world. International Studies Quarterly 41 (3): 435-54.

Miniane, Jacques. 2004. A new set of measures on capital account restrictions. IMF Staff Papers 51 (2): 276-308. Washington, DC: International Monetary Fund.

Mody, Ahoka, and Antu P. Murshid. 2002. Growing up with capital flows. IMF Working Paper no. WP/02/75. Washington, DC: International Monetary Fund, April.

Montiel, Peter, and Carmen Reinhart. 1999. Do capital controls and macroeconomics policies influence the volume and composition of capital flows? Evidence from the 1990s. Journal of International Money and Finance 18 (4): 619-35.

Quinn, Dennis P. 1997. The correlates of changes in international financial regulation. American Political Science Review 91:531-51.

2003. Capital account liberalization and financial globalization, 1890-1999: A synoptic view. International Journal of Finance and Economics 8 (3): 189-204.

Quinn, Dennis P., and Ana Maria Toyoda. 2003. Does capital account liberalization lead to economic growth? An empirical investigation. Georgetown University. Mimeograph. 
Razin, Asaaf, and Andrew K. Rose. 1994. Business cycle volatility and openness: An exploratory cross-section analysis. In Capital mobility: The impact on consumption, investment and growth, ed. L. Leiderman and A. Razin, Cambridge, UK: Cambridge University Press.

Stiglitz, Joseph. 2002. Globalization and its discontents. New York: W. W. Norton.

\section{Comment Edmar L. Bacha}

Edwards's paper is an important contribution to the debate on the impact of financial openness on output volatility. Reading this paper was for me a most rewarding educational experience. But in my role as discussant I focus on doubts and divergences.

First, I find it difficult to understand Edwards's postulated direction of causality between current account reversals and gross domestic product (GDP) slowdowns, for it is easy to understand that GDP contractions lead to current account reversals, through fewer imports and more exports. The reverse mechanism is less clear. Causality thus seems to be the opposite of that assumed in the paper. The use of dummies to focus only on major current account reversals does not seem to resolve this causality issue.

Second, sudden capital stops should lead first to international reserve losses and only then to GDP contractions. There is thus a time lag in the causation chain that is not considered in the paper. Moreover, Edwards's net capital inflow variable seems to suffer from measurement problems. The first problem is that Edwards includes the "errors and omissions" item of the balance of payments as part of the capital flows, when in fact it also includes unimputed current account items. One wonders if his econometric tests would be robust to a shift to the current account of the "errors and omissions" item. More importantly, compensatory/official financing is included in the net capital inflow variable, thus making it less procyclical, as output falls may be expected to be accompanied by more compensatory/ official financing. The relevant exogenous variable for Edwards's tests should be lagged net private capital inflow rather than current total capital inflow. The use of an inadequate variable for capital inflows and the impact of output changes on the trade balance may explain why Edwards finds GDP contractions to have a weaker correlation with sudden stops than with current account reversals.

A third problem is the use of a "country" independently of size as the unit of observation. This tends to bias Edwards's results toward the experience of the more fragile Africa's and island economies. A weighted re-

Edmar L. Bacha is director of the Casa das Garças Institute for Economic Policy Study in Rio de Janeiro, Brazil. 
gression, with countries being weighted either by population or GDP, would solve this problem.

My fourth point requires a digression on Brazil's experience since 1970. In table 3C.1, one can observe five episodes of GDP slowdowns, defined as growth rates lower than 1 percent: 1981 to $1983,1988,1990$ to 1991,1998 to 1999,2003 . The first observation is that none is associated to a "hard" current account reversal or a sudden stop, defined as variation of 4 percent of GDP — as these never occurred. Only 2003 is associated to a soft sudden stop (2 percent of GDP), whereas 1983, 1989, and 2003 are associated to soft ( 2 percent of GDP) current account reversals. This evidence would seem to justify Edwards's assertion that sudden stops by themselves are not as important as current account reversals to explain GDP contractions. Note, however, in the table that substantial reserves losses occurred either previously to or simultaneously with the GDP slowdowns. More often than not, such reserves losses were associated to domestic factors rather than international shocks - the blow-up of the "Brazilian miracle" in the early 1980s, the failed Cruzado plan of 1986, the after-effect of the 1994 exchange rate based stabilization, and the "fear of Lula" in 2002. Thus,

Table 3C.1

Brazil's GDP slowdowns and external shocks, 1970-2004

\begin{tabular}{rrrrrrrrr}
\hline Year & \multicolumn{1}{c}{ CA } & Y $\$$ & Y\% & NKI & deltaR & deltaR/Y\$ & dCA/Y\$ & dNKI/Y\$ \\
\hline 1979 & $-10,708$ & 222,285 & & 7,624 & $-3,214$ & -1.45 & & \\
1980 & $-12,739$ & 236,841 & 9.2 & 9,610 & $-3,472$ & -1.47 & 0.91 & 0.89 \\
1981 & $-11,706$ & 257,269 & -4.25 & 12,746 & 625 & 0.24 & -0.44 & 1.32 \\
1982 & $-16,273$ & 269,900 & 0.83 & 12,101 & $-4,542$ & -1.68 & 1.78 & -0.25 \\
1983 & $-6,773$ & 188,532 & -2.93 & 7,419 & -24 & -0.01 & -3.52 & -1.73 \\
1986 & $-5,323$ & 256,509 & 7.49 & 1,432 & $-3,836$ & -1.50 & & \\
1987 & $-1,438$ & 280,949 & 3.53 & 3,259 & 1,015 & 0.36 & -1.51 & 0.71 \\
1988 & 4,180 & 304,185 & -0.06 & $-2,098$ & 1,249 & 0.41 & -2.00 & -1.91 \\
1989 & 1,032 & 413,564 & 3.16 & 629 & 886 & 0.21 & 1.03 & 0.90 \\
1990 & $-3,784$ & 466,635 & -4.35 & 4,592 & 481 & 0.10 & 1.16 & 0.96 \\
1991 & $-1,407$ & 405,097 & -2.93 & 163 & -369 & -0.09 & -0.51 & -0.95 \\
1992 & 6,109 & 387,277 & 5.4 & 9,947 & 14,670 & 3.79 & -1.86 & 2.42 \\
1997 & $-30,452$ & 807,215 & 3.27 & 25,800 & $-7,907$ & -0.98 & & \\
1998 & $-33,416$ & 787,346 & 0.13 & 29,702 & $-7,970$ & -0.01 & 0.37 & 0.48 \\
1999 & $-25,335$ & 536,318 & 0.79 & 17,319 & $-7,822$ & -1.16 & -1.03 & -1.57 \\
2000 & $-24,225$ & 601,942 & 4.36 & 19,326 & $-2,262$ & -0.38 & -0.21 & 0.37 \\
2001 & $-23,215$ & 509,623 & 1.31 & 27,052 & 3,307 & 0.65 & -0.17 & 1.28 \\
2002 & $-7,637$ & 460,732 & 1.93 & 8,004 & 302 & 0.07 & -3.06 & -3.74 \\
2003 & 4,177 & 505,533 & 0.54 & 5,111 & 8,496 & 1.68 & -2.56 & -0.63 \\
2004 & 11,669 & 626,346 & 5.20 & $-7,310$ & 2,244 & 0.36 & -1.18 & -2.46 \\
\hline
\end{tabular}

Source: Institute of Applied Economic Research (IPEA) data.

Notes: $\mathrm{CA}=$ Current account in US\$ millions; Y $\$=$ GDP in US\$ millions; Y\$ = GDP growth rate; $\mathrm{NKI}=$ net capital inflows in US\$ millions; deltaR = change in international reserves in US\$ millions; $\mathrm{dCA}=$ change in the current account in US\$ millions; $\mathrm{dNKI}=$ change in net capital inflows in US\$ millions. 
Brazil's experience suggests that the relevant variable for growth slowdowns should be the cumulative reserve loss (i.e., current account deficits systematically higher than net capital inflows), rather than current account reversals or sudden stops by themselves. Perhaps this could be a good starting point for a new Edwards's paper on the subject.

Finally, in the original paper a critical variable was missing - the exchange rate regime. Supposedly floating rates help mitigate sudden capital splurges/stops as well as current account reversals, thus leading to less GDP volatility. The paper now allows for this variable, and it does have the expected impact. However, Edwards still does not provide an adequate test for the impact of exchange rate regime change on the statistical significance of the dummies standing for the current account reversals and the sudden stops.

\section{Comment Marcelo Kfoury Muinhos}

This is a very interesting paper that tries to shed light on an important issue related to the real effects of cross-border capital movements. The paper is an empirical one, and, as such, the required tests present several difficulties, especially regarding a study that works with economic data for a wide range of countries.

The paper presents the argument's procapital controls: (a) It reduces a country's vulnerability to external shocks and financial crisis, and (b) it allows countries that suffered a currency crisis to lower interest rate, implement progrowth policies, and emerge out of the crisis sooner.

The objective of the paper is to go against capital control and so disqualify those claims. There is some evidence that high capital mobility is not correlated with current account reversal or sudden stops. At least for high capital mobility, the incidence of current account reversal is lower (table $3.4, \mathrm{H} \neq \mathrm{L}$ ).

For sudden stops, the paper does show little statistical evidence that they occur more or less frequently in more open or closed capital accounts (table 3.5).

In section 3.4, when he presents the second estimation of growth dynamics, the coefficients that interact with the crisis indicator and capital are found not significant (table 3.8), so it is not possible to insure that the more open the capital account is, the less severe is the crisis after, so he could not have evidence against claim $b$. 
In section 3.3.1, Edwards explained how his index of capital mobility was calculated.

- It fills the gap of missing variables using a STATA's impute procedure.

- He used a two-order index, their lagged values, and two definitions of openness.

One important aspect that is not present in the index is the amount of inflow and outflow of capital. Large current account deficits may therefore imply large capital inflows. Capital mobility is also related to the liquidity condition in the international capital markets; that is, supply and demand conditions in the home and host countries of capital have to be taken into consideration. It seems inconvenient to dissociate current account reversal from sudden stops as these two effects are part of just one event.

Developments in the external current account are directly related to the inflows of capital to finance deficits - directly through trade financing or indirectly through other capital inflows. If the country suffers a sudden stop crisis, it is healthy if it is able to promote a current account reversal. This reversal in general has an expenditure-switching component promoted by the exchange rate devaluation and a reduction of expenditure that causes recession.

My question is related to whether the standard errors in the growth equations are corrected for the fact that the "reversal variable" is estimated in a previous step. He uses a treatment with an instrument variable to avoid endogeneity problems. So I think it is fine. 